\title{
LA DELIMITACIÓN DEL OBJETO DE LA CONTROVERSIA EN LA AUDIENCIA PREVIA DEL JUICIO ORDINARIO*
}

\author{
Carlos de Miranda VÁzQuez \\ Profesor de Derecho Procesal \\ Facultat de Dret de la Universitat \\ Internacional de Catalunya \\ cdemiranda@uic.es
}

\begin{abstract}
RESUMEN
Entre otros factores, la precisa, correcta y eficiente delimitación del objeto de la controversia contribuye sustancialmente a la calidad de la sentencia que se dicte en primera instancia. Por consiguiente, esta actividad procesal, inserta en la audiencia previa como un trámite más, se revela de capital importancia. Asimismo, aquélla se encuentra disciplinada por un precepto, el art. 428 LEC, que presenta numerosos problemas, tanto por su redacción como a la bora de su aplicación en la práctica forense. Pues bien, el propósito de este trabajo es hacer inventario de todos esos inconvenientes y sugerir posibles soluciones para los mismos. En última instancia, se aspira a contribuir modestamente a la mejora de la regulación de la actividad delimitadora del objeto de la controversia y, por ende, al perfeccionamiento de esta útil herramienta que presta un servicio significativo a la calidad de la justicia civil.

Palabras clave: juicio civil declarativo ordinario, audiencia previa, función delimitadora del objeto de controversia, fijación de hechos pacíficos y controvertidos.
\end{abstract}

\section{ABSTRACT}

Among other factors the specific, accurate and efficient framing of the object of controversy clearly leads to the good quality of the initial sentence. Therefore, this procedural activity, as part of the requirements of the audience prior to it proves to be fairly important. Also, the latter is ruled by a precept, art. 428 of Civil Prosecution Law, which has a number of problems in its wording as when to be implement-

* Este trabajo se enmarca en el proyecto de investigación «Las funciones delimitadora y probatoria de la audiencia previa (una revisión crítica de los arts. 426 a 429 LEC)», reconocido y financiado por la fundación privada Manuel Serra Domínguez, en la primera convocatoria pública de ayudas a la investigación en temas de Derecho procesal que se falló el 10 de noviembre de 2015. Quiero agradecer expresamente las atinadas observaciones de los profesores PICÓ I JUNOY y ANDINO LÓPEZ, que sin duda alguna han contribuido, significativamente, a mejorar la versión inicial de este trabajo. 
ed in forensic law. So, the reason for this study is to take inventory of such inconvenience and to suggest likely solutions to them. All in all we aim at contributing toward an improvement of the ruling of the activity which frames the object of controversy and eventually to the improvement of such useful tool toward the good quality of civil law practice.

Keywords: Ordinary Declarative Civil Judgement, Prior Audience, the task to frame the object of controversy, Setting of peaceful and controversial facts.

\section{ZUSSAMENFASSUNG}

Neben anderen Faktoren, trägt die präzise und effiziente Abgrenzung des Streitgegenstands wesentlich zur Qualität des Urteils bei, welches in erster Instanz verkündet wird. Infolge dessen hat diese Prozesshandlung, eingebettet in die vorherige Anhörung, eine herausragende Bedeutung. Daher wird diese durch die Vorschrift des Art. 428 der spanischen Prozessordnung (LEC), welche vielzählige Probleme aufweist, sowohl bezogen auf ibre Abfassung, als auch bei der Anwendung in der Gerichtspraxis. Die Absicht dieser Arbeit besteht nun darin, eine Inventarliste all dieser nachteiligen Umstände zu erstellen und mögliche Lösungen für sie anzubieten. Im Letzten bestebt der Anspruch des Autors darin, in bescheidener Weise zur Verbesserung der gesetzlichen Regelungen dieser Tätigkeit der Eingrenzung des Streitgegenstands beizutragen, um dieses nützliche Werkzeug, welches einen bedeutenden Beitrag zur Qualität der Ziviljustiz leistet, zu verbessern.

Schlüsselwörter: ordentlicher deklaratorischer Zivilprozess, vorherige Anhörung, abgrenzende Funktion des Streitgegenstands, Festlegung von friedlichen und kontroversen Tatbeständen.

SUMARIO: I. INTRODUCCIÓN.-II. EL OBJETO DE DELIMITACIÓN EN EL TRÁMITE DEL ART. 428.1 LEC.-III. ¿QUÉ QUEDA FUERA DEL ÁMBITO OBJETIVO DEL ART. 428 LEC?-IV. ¿QUIÊN FIJA LOS HECHOS PACÍFICOS Y LOS CONTROVERTIDOS?-V. EL DESARROLLO DE LA ACTIVIDAD DELIMITADORA.-VI. LA INTERVENCIÓN DECISORA DEL JUEZ EN EL CASO DE REGISTRARSE DISCREPANCIAS ENTRE LAS PARTES.-VII. BREVE EXCURSO: LA NECESIDAD DE QUE EL ART. 405.2 IN FINE LEC SE APLIQUE EN ESTE MOMENTO PROCESAL.-VIII. UNA APUESTA POR LA EFICIENCIA PROCESAL: LA RELACIÓN ÚNICA DE HECHOS.-IX. LA «EXHORTACIÓN» JUDICIAL DEL APARTADO 2. ${ }^{\circ}$ DEL ART. 428 LEC.-X. EL TRATAMIENTO PROCESAL DE LA AUSENCIA DE CONTROVERSIA FÁCTICA.-XI. LA INADECUADA LOCALIZACIÓN SISTEMÁTICA DEL ART. 428 LEC.-XII. APUNTE FINAL: UNA PROPUESTA DE LEGE FERENDA.

\section{INTRODUCCIÓN}

Considero innecesario reafirmarme en las numerosas bondades que comporta una correcta delimitación del objeto de la controversia en la audien- 
cia previa. Se ha escrito mucho al respecto y no quisiera incurrir en reiteraciones innecesarias que me aparten del propósito específico del trabajo ${ }^{1}$.

La intención que alienta este trabajo es el análisis detenido, concienzudo, de la norma que disciplina la delimitación de la disputa en la audiencia previa del juicio ordinario. Me refiero al art. 428 de la Ley de Enjuiciamiento Civil (en adelante, LEC) ${ }^{2}$. El interés que despierta este precepto radica, en primer lugar, en los cuantiosos problemas que presenta al pretender aplicarlo en la práctica ${ }^{3}$.

En segundo lugar, e íntimamente vinculado con lo anterior, dicho interés reside en la heterogénea aplicación que se hace del mismo en los tribunales de justicia ${ }^{4}$. El objetivo pretendido, en último término, es contribuir, en alguna medida, a su futura mejora, con una innegable perspectiva de lege ferenda.

A propósito de dicha norma, me veo en la obligación de efectuar una precisión conceptual previa. Se me puede objetar, y con razón, que no es el art. 428 LEC el único precepto que se ocupa de la delimitación de la controversia, dentro, incluso, de la propia audiencia previa. Son numerosos los autores que extienden la función delimitadora — en el marco de la audiencia previa - a otros artículos, como puedan ser el art. 426 y el $427^{5}$. Insisto, no les falta la razón. Por supuesto, fuera de la audiencia pre-

${ }^{1}$ Sobre este particular, y por extenso, vid. C. DE Miranda VÁzQuez, «Luces y sombras del art. 428.1 de la Ley de Enjuiciamiento Civil: un análisis etiológico», Diario La Ley, núm. 8310, año XXXIV (2014), pp. 9-17.

2 «Art. 428. Fijación de los bechos controvertidos y posible sentencia inmediata. 1. En su caso, la audiencia continuará para que las partes o sus defensores, con el tribunal, fijen los hechos sobre los que exista conformidad y disconformidad de los litigantes. 2. A la vista del objeto de la controversia, el tribunal podrá exhortar a las partes o a sus representantes y a sus abogados para que lleguen a un acuerdo que ponga fin al litigio. En su caso, será de aplicación al acuerdo lo dispuesto en el art. 415 de esta Ley. 3. Si las partes no pusieran fin al litigio mediante acuerdo, conforme al apartado anterior, pero estuvieren conformes en todos los hechos y la discrepancia quedase reducida a cuestión o cuestiones jurídicas, el tribunal dictará sentencia dentro de veinte días a partir del siguiente al de la terminación de la audiencia».

3 A este respecto me remito al exhaustivo análisis de A. URIARTE CORDón, «La fijación de los hechos controvertidos como presupuesto del juicio sobre la admisión de los medios de prueba», en X. Abel Lluch y J. Picó i Junoy (dirs.), Aspectos prácticos de la prueba civil, Barcelona, Bosch, 2006, pp. 97-100.

${ }^{4}$ Una inmejorable radiografía de la penosa situación presente en la práctica forense se recoge en el trabajo de A. CAPIlla Casco y J. Sánchez-Lozano Velasco, «Patologías de la audiencia previa (I) (hechos controvertidos, la aplicación del art. 210 de la LEC y la recurribilidad de la admisión de prueba)», Economist E Jurist, año XXII, núm. 185 (2014), p. 67.

5 Entre otros muchos, J. DAmí́n Moreno, «La audiencia previa al juicio», en V. Cortés Domínguez y V. Moreno Catena (coords.), La nueva Ley de Enjuiciamiento Civil, t. II, Madrid, Tecnos, 2000, p. 96; M. R. GutIÉRREZ SANZ, «La audiencia previa», en J. C. CABAÑAS (coord.), Comentarios prácticos a la nueva Ley de Enjuiciamiento Civil, Madrid, Trivium, 
via también se hallarían normas a las que se les podría atribuir una finalidad delimitadora de la controversia ${ }^{6}$. Piénsese, como el ejemplo más nítido, en el apartado $2{ }^{\circ}$ del art. 405, en su parte final ${ }^{7}$. Pese al acierto de tal observación, tengo para mí que únicamente se puede hablar de función delimitadora en el caso del art. 428.1 LEC, al menos en sentido estricto $^{8}$. No niego — porque salta a la vista - que el art. 405.2 in fine LEC presta un gran servicio a la causa de la delimitación ${ }^{9}-\mathrm{o}$ mejor, lo prestaría si su redacción no fuese incompleta, como se verá más adelante-. Tampoco se me oculta que la actividad dialéctica que encierra, por ejemplo, el art. 426 LEC, especialmente en su apartado $1 .^{\circ}$-las «alegaciones complementarias»- ${ }^{10}$, contribuye a la fijación de la disputa fáctica. Pero en todos esos casos se cumple el cometido indirectamente, en tanto en cuanto el movimiento dialéctico lleva implícito la delimitación de los puntos de encuentro y desencuentro. No obstante lo anterior, lo que en dichos artículos (especialmente los arts. 405.2 in fine, 426.1 y 427 LEC) hay de demarcación del debate es indirecto o consustancial a su propia esencia dialéctica. Dicho de otra manera, toda fase de alegaciones en un proceso declarativo per se comporta, de forma intrínseca e implícita, la demarcación de los términos del debate. Sin embargo, es en el trámi-

2000, p. 400; J. BAnACloche PALAO, «Art. 428. Fijación de los hechos controvertidos y posible sentencia inmediata», en AAVV, Comentarios a la Ley de Enjuiciamiento Civil, Madrid, Civitas, 2001, p. 722, y X. ABEL LLUCH, «La audiencia previa: entre el deseo y la realidad», Revista del Poder Judicial, núm. 69 (2003), pp. 336-337.

${ }^{6}$ Por todos, cfr. F. J. Muñoz Jiménez, «Actos de las partes delimitadores del objeto del proceso: demanda, contestación, réplica, dúplica, escrito de ampliación y conclusiones», Cuadernos de Derecho Judicial, núm. 23 (1996), pp. 149-220.

7 Cfr. I. Tapia FernándeZ, «Art. 428. Fijación de los hechos controvertidos y posible sentencia inmediata», en F. Cordón Moreno, T. Armenta Deu, J. J. Muerza Esparza e I. TAPIA FERnÁndez (coords.), Comentarios a la Ley de Enjuiciamiento Civil, vol. 1, 2." ed., Cizur Menor, Aranzadi-Thomson Reuters, 2011, p. 1798.

${ }^{8}$ En este sentido, J. Alonso-Cuevillas y SAYrol (coord.), «La audiencia previa al juicio», en Instituciones del nuevo proceso civil. Comentarios sistemáticos a la Ley 1/2000, vol. II, Barcelona, Difusión Jurídica y Temas de Actualidad, 2000, p. 162, se ocupa de distinguir dentro de la función delimitadora, de muy amplio rango, la subfunción dialéctica que reserva con evidente acierto para el art. 426 LEC.

9 Como afirma M. A. Díez García, «Consecuencias de la negativa de una de las partes a fijar los hechos controvertidos», en X. ABeL Lluch y J. Picó i Junoy (dirs.), La audiencia previa, Barcelona, Bosch, 2010, p. 342, «esa fijación [en referencia al art. 428 LEC] parece que podría resultar innecesaria, puesto que en la contestación debería haber dejado ya sentados puntos de conformidad y discrepancia».

${ }_{10}$ Con respecto a esta cuestión me remito, por extenso, y con abundante bibliografía, a C. DE Miranda VÁzquez, «Problemática de las alegaciones complementarias en el proceso civil. Estudio del art. 426.1 de la Ley de Enjuiciamiento Civil», Revista Jurídica de Catalunya, núm. 4 (2014), pp. 141-161. 
te procesal comprendido en el art. 428 LEC donde la actividad delimitadora se torna explícita, donde procesalmente se lleva a cabo la verdadera delimitación del objeto de la controversia con precisión y de modo definitivo $^{11}$. A lo que se suma que dicho precepto no contempla actividad alegatoria alguna ${ }^{12}$. Y, aún mejor, es entonces cuando esa actividad de fijación que se ha desarrollado de forma soterrada, tácita, a lo largo de toda la fase de alegaciones —escritas y orales - se formaliza y se fija definitivamente. De aquí que pueda decirse que la actividad propia del art. 428 LEC es tributaria de toda la dialéctica previa, que va más allá de los lindes de la audiencia previa, encontrando su comienzo en la fase de alegaciones escritas.

Antes de entrar de lleno en el estudio que nos debe ocupar, aún resta por efectuar otra disquisición que estimo pertinente a los efectos de evitar malos entendidos. Se ha sostenido en la literatura científica ${ }^{13}$ que la función delimitadora, capital, tiene lugar en el trámite contemplado en el apartado 6..$^{\circ}$ del art. 426 LEC $^{14}$. No comparto, sin embargo, tal postulado. La finalidad de esta última norma no es otra que disciplinar la iniciativa del tribunal en relación con la aclaración o precisión de afirmaciones, de hecho o de derecho, contenidas en los escritos rectores que se estimen oscuras, confusas, ininteligibles o incluso erróneas ${ }^{15}$. En otras palabras, no

${ }^{11}$ Cfr. SAP Tarragona (Sección 3. ${ }^{a}$ ) núm. 180/2011, de 28 de abril, fundamento jurídico $2 .^{\circ}$ (JUR 2011/260102).

12 Con razón A. URIARTE CoRdón, «Sujetos que deben realizar la fijación de los hechos controvertidos (art. 428.1 LEC). Especial atención al juicio verbal», en X. ABEL LLUCH y J. Picó I Junoy (dirs.), La audiencia previa, Barcelona, Bosch, 2010, p. 336, atisba un serio riesgo de que el trámite del art. 428 LEC se convierta en una fase de alegaciones, cuando no lo es.

${ }^{13}$ Principalmente M. SerRano Masip, «La iniciativa del tribunal tendente a determinar el objeto de la controversia en el proceso civil. Análisis del art. 426.6 de la Ley de Enjuiciamiento Civil», Justicia: Revista de derecho procesal, núm. 1-2 (2004), pp. 193-230.

14 «Art. 426. Alegaciones complementarias y aclaratorias. Pretensiones complementarias. Hechos acaecidos o conocidos con posterioridad a la demanda y la contestación. Presentación de documentos sobre dichos extremos. [...] 6. El tribunal podrá también requerir a las partes para que realicen las aclaraciones o precisiones necesarias respecto de los hechos y argumentos contenidos en sus escritos de demanda o contestación. Si tales aclaraciones o precisiones no se efectuaren, el tribunal les advertirá de que puede tenerlos por conformes con relación a los hechos y argumentos aducidos de contrario».

${ }^{15}$ Lo entiende así J. Alonso-Cuevillas y Sayrol, «La audiencia previa...», op. cit., pp. 161 y 162. Con acierto señala este autor que la «subfunción aclaradora» —claramente diferente de la «subfunción concretora»- se localiza exclusivamente en los apartados $2 .^{\circ}$ y $6 .^{\circ}$ del art. 426 LEC. También lo contempla de este modo E. Rodríguez AchúTEGUI, «Art. 426. Alegaciones complementarias y aclaratorias. Pretensiones complementarias. Hechos acaecidos o conocidos con posterioridad a la demanda y la contestación. Presentación de documentos sobre dichos extremos», en J. A. XIOL Ríos (coord.), Enjuiciamien- 
es su finalidad la delimitación del objeto de la controversia, sino que tiene otra pretensión mucho más modesta como es la de perfeccionar los extremos de la dialéctica — escrita- que adolezcan de cualquier deficiencia que le dificulte al juzgador —o a las partes— su correcta comprensión ${ }^{16}$. Nótese que justo antes de la aplicación del art. 428 LEC, la norma prevé una aclaración y precisión del objeto de la controversia (art. 426 LEC) para así facilitar su efectiva fijación posterior (art. 428 LEC).

\section{EL OBJETO DE DELIMITACIÓN EN EL TRÁMITE DEL ART. 428.1 LEC}

Estimo que ofrece pocas dudas el hecho de que, principalmente - $y$, como veremos más adelante, únicamente-, el apartado $1 .^{\circ}$ del art. 428 LEC se consagra a la delimitación de la controversia fáctica.

Lo que sí entiendo disputado, en cambio, es si la fijación atiende únicamente a los hechos controvertidos o también deben ser objeto de atención - y de mención, claro- los hechos pacíficos. A la vista del tenor literal del apartado $1 .^{\circ}$ del art. 428 LEC así es, o, al menos, así debería ser ${ }^{17}$. Sin embargo, en la práctica del foro constituye una costumbre generalizada orillar los hechos pacíficos ${ }^{18}$. Aunque creo que este fenómeno obede-

to Civil. Comentarios y jurisprudencia. Ley 1/2000, de 7 de enero, vol. II, Las Rozas, Sepin, 2008, p. 2627.

${ }_{16}$ Para un estudio en profundidad del art. 426.6 LEC vid. C. DE Miranda VázQuez, «El apartado 6. ${ }^{\circ}$ del art. 426 LEC: crónica de una norma fallida», Justicia. Revista de Derecho Procesal, núm. 2 (2016), pp. 255-300.

${ }^{17}$ Cfr. J. Hoya Coromina, «Art. 428. Fijación de los hechos controvertidos y posible sentencia inmediata», en J. M. Fernández-Ballesteros, J. M. Rifá Soler y J. F. Valls GomBAU (coords.), Comentarios a la nueva Ley de Enjuiciamiento Civil, t. I, Barcelona, IurgiumAtelier, 2000, p. 1904; J. Banacloche PalaO, «Art. 428...», op. cit., p. 722; S. Barona VIlaR, «Art. 428. Fijación de los hechos controvertidos y posible sentencia inmediata», en F. EsCRIBano Mora (coord.), El proceso civil, vol. 4, Valencia, Tirant lo Blanch, 2001, p. 3201; E. Rodríguez Achútegui, «Art. 428. Fijación de los hechos controvertidos y posible sentencia inmediata», en J. A. XIol Ríos (coord.), Enjuiciamiento Civil. Comentarios y jurisprudencia. Ley 1/2000, de 7 de enero, vol. II, Las Rozas, Sepin, 2008, pp. 2636-2637, y A. CaPILla Casco y J. Sánchez Lozano Velasco, «Patologías...», op. cit., p. 68. Para J. Alonso-CueviLLAS y SAYROL, La comparecencia preparatoria del juicio de menor cuantía, Barcelona, Bosch, 1992, p. 299, ya constituía casi una obviedad en tiempos de la ALEC. Entre la jurisprudencia menor, y por todas, SAP Valencia (Sección 1. ${ }^{a}$ ), núm. 109/2006, de 14 de marzo, fundamento jurídico 2. ${ }^{\circ}$ (AC 2006/1498).

18 Así, A. Capilla Casco y J. Sánchez-Lozano Velasco, «Patologías...», op. cit., p. 68, y J. Arsuaga Cortázar, «Art. 428. Fijación de los hechos controvertidos y posible sentencia inmediata», en F. MARín CASTÁN (dir.), Comentarios a la Ley de Enjuiciamiento Civil, t. II, 
ce a una simple cuestión pragmática —el tiempo apremia en las agendas judiciales-, no puedo evitar pensar en que quizá el título del precepto alimenta la confusión. Éste reza «fijación de los hechos controvertidos» y ninguna alusión contiene a los pacíficos. No obstante, desecho semejante conjetura porque se antoja excesivamente rebuscada, cuando el propio legislador seguramente se vio acuciado por las mismas exigencias de pragmatismo - y sincretismo - que los aplicadores cuando abordan este trámite procesal en el decurso de las apresuradas audiencias previas. Por consiguiente, y en definitiva, deben fijarse ambas clases de hechos, por más que las prisas apremien.

Se ha sugerido, sensatamente, que, pese a que no se exprese en el tenor literal del precepto concernido, constituye una inmejorable ocasión para eliminar material fáctico irrelevante o sobrante ${ }^{19}$. No me parece exagerado afirmar que, con frecuencia, en los escritos de alegaciones iniciales se introduce información fáctica que a medida que se avanza en el curso dialéctico se torna innecesaria ${ }^{20}$. Esos datos fácticos que no hayan de aprovechar en absoluto al enjuiciamiento de la controversia, o que sólo pretendían introducir al juzgador en el epicentro del debate —una vez leídos por el órgano jurisdiccional con ocasión de la preparación de la audiencia previa-, pueden —incluso deben — ser desechados ${ }^{21}$. Y ello en aras a simpli-

Valencia, Tirant lo Blanch, 2015, p. 2049. También parece haber cundido la desatención de los hechos pacíficos entre la doctrina científica, como es de ver, por ejemplo, en L. PuENTE DE PINEDO, «Art. 428. Fijación de los hechos controvertidos y posible sentencia inmediata», en F. Toribios Fuentes (coord.), Comentarios a la Ley de Enjuiciamiento Civil, Valladolid, Lex Nova, 2012, p. 697.

19 Sugiere este cometido J. Alonso-Cuevillas y Sayrol, La comparecencia preparatoria..., op. cit., pp. 295 y 299-300, e íD., «La audiencia previa...», op. cit., pp. 161, 166 y 167. A este respecto me parece muy oportuna la reflexión de A. BONET NAVARRO, La nueva comparecencia del juicio de menor cuantía, Barcelona, Bosch, 1988, p. 115, cuando - aún en tiempos de la ALEC - apuntaba la conveniencia de que en esta clase de trámite se llevara a cabo una actividad similar a la de las «pre-trial conferences» estadounidenses, en las que se consigue sintetizar el conflicto y simplificar el objeto del litigio para que el jurado pueda manejar toda la información imprescindible con mayor comodidad. Parece sostener lo contrario E. Rodríguez AchúteguI, «Art. 428...», op. cit., p. 2637, quien considera que esa criba debe quedar para el momento de dictarse sentencia.

20 A. URIARTE Cordón, «Sujetos...», op. cit., pp. 334 y 336, sostiene que la delimitación ha de conjugarse con los presupuestos o requisitos de la acción a los efectos de excluir del debate aquellos hechos que no guarden relación con aquéllos. En el mismo sentido, M. A. Díez García, «Consecuencias...», op. cit., p. 344, considera que la delimitación debe relacionarse con requisitos de acción ejercitada.

${ }^{21}$ Un posible ejemplo de dicha depuración del contenido fáctico relevante para la resolución de la controversia lo encontramos en SAP Madrid (Sección 9. ${ }^{a}$ ), núm. 403/2014, de 9 de octubre, fundamento jurídico 3. ${ }^{\circ}$ (JUR 2014/298156). 
ficar los términos del —verdadero- debate y a minimizar la eventual posterior actividad probatoria. Bien es cierto que se me podría objetar que no es necesario salirse de los lindes de la dicción legal para conseguir un objetivo que podría alcanzarse igualmente con la mera conformidad de la contraparte. Dicho más sencillamente, bastaría con que las partes los considerasen pacíficos. Aunque comparto esta observación, al objeto de elaborar el que denominaré «proyecto de sentencia en cuanto a los hechos»-y desarrollaré más adelante- resultaría muy provechoso que el juez, con la anuencia de las defensas técnicas, pudiera acometer dicha labor de poda del material fáctico ocioso o inútil.

No puede dejarse de mencionar la sugerencia, ciertamente atinada, de que se aproveche el trámite del art. 428.1 LEC para que el juez determine, cuando corresponda, aquellos hechos que gozan «de notoriedad absoluta y general» (según reza el art. 281.4 LEC) ${ }^{22}$. La proposición que nos ocupa merece ser considerada detenidamente, porque no resulta, ni con mucho, tan sencilla como aparenta. Fundamentalmente porque el art. 281.4 LEC lo único que establece es que este tipo de hechos no precisan de prueba. Sin embargo, dicha norma no establece cuándo deba el juez pronunciarse sobre si unos hechos revisten tal notoriedad o no ${ }^{23}$. Que la cuestión se reserve para el momento de dictar sentencia entraña un grave riesgo de que entonces el órgano jurisdiccional les niegue tal condición. En aquel momento posterior será tarde para articular prueba al respecto ${ }^{24}$. Por el contrario, cabe pensar que si uno de los litigantes aseveró en su escrito rector que tal o cual hecho goza de notoriedad, será éste el momento idóneo para concluir si es así, de modo que, en el caso de verse rechazada tal pretensión, la parte pueda interesar la prueba que mejor le convenga para probarlo. Bien es cierto que la redacción legal del apartado $1{ }^{\circ}$ del art. 428 LEC no contiene ni tan siquiera trazas de que pueda ventilarse la cuestión concernida en este trámite. Sin embargo, entiendo que son muchos y robustos los argumentos que permiten abogar a favor de esta lectura prae-

${ }^{22}$ Lo sugieren S. Barona Vilar, «Art. 428...», op. cit., p. 3202; J. F. Garnica MarTín, «La delimitación del objeto de la controversia en la audiencia previa (y II)», Economist E Jurist, núm. 135 (2009), pp. 58-59, y A. Capilla Casco y J. Sánchez Lozano Velasco, «Patologías...», op. cit., p. 68.

${ }^{23}$ Con respecto a los problemas que suscita la regulación de los hechos notorios, me remito al interesante trabajo de J. ArRIBAS Altarriba, «La prueba del hecho notorio», en X. Abel Lluch y J. Picó i Junoy (dirs.), Objeto y carga de la prueba civil, Barcelona, Bosch, 2007, pp. 343-367.

${ }_{24}$ Así, López Simó, a quien sigue y cita J. Arribas Altarriba, «La prueba...», op. cit., p. 357. 
ter legem ${ }^{25}$. Amén de que se trata de la solución más respetuosa del derecho a la prueba de los justiciables, que de esta forma no pierden la oportunidad de probar unos hechos que, a pesar de considerarlos notorios, el juzgador no los reputa tales ${ }^{26}$.

Ahora bien, la tesis defendida encierra una notable dificultad. Por una parte, no es posible extraer del apartado $1 .^{\circ}$ del art. 428 LEC la forma de tramitar este particular «incidente» sobre el carácter notorio de un determinado hecho. Es más, tampoco ése es el propósito específico del precepto concernido. Por otra parte, para llegar a la conclusión de que un hecho es efectivamente notorio, cuando se muestre disconforme la parte contraria, se hace necesaria una resolución judicial que así lo establezca y que no es idéntica a la que consideramos implícita en el trámite del art. 428.1 LEC. No se trata aquí de decidir si existe consenso o discrepancia sobre un hecho, sino sobre si el mismo reviste la pretendida notoriedad. Además, habida cuenta que la Ley no grava a las partes — como debería hacerlo — con la carga de afirmar la condición de notorio de un hecho, en los escritos rectores, y de admitirlo o negarlo, de adverso, puede ocurrir que el conflicto sobre el particular emerja precisamente en el trámite del art. 428.1 LEC. Bien es verdad que un hecho notorio no puede equipararse a un hecho admitido. Por lo que tampoco sería de extrañar que la parte interesada no advirtiera dicha condición confiando en lo evidente de la misma, originándose el problema al notificársele la sentencia, donde no se le ha reconocido tal calidad al hecho. Sea como fuere, con ocasión del trámite del art. 428.1 LEC, o aprovechándolo oportunamente, deberá arbitrar el juez una suerte de incidente en el que las partes manifiesten lo que tengan por conveniente y, acto seguido, resuelva oralmente lo que estime oportuno (art. 210 LEC).

Otro cometido que se ha pensado para este trámite, nuevamente escapando al rígido corsé de la redacción legal, es el de determinar qué máximas de experiencia resultan pacíficas y cuáles son controvertidas ${ }^{27}$. Pese a la loable intención que entraña esta propuesta, me temo que tiene un recorrido muy corto. Primeramente, porque en la generalidad de los casos, las partes no explicitan —en sus respectivos escritos rectores— las máximas de expe-

25 J. Montero Aroca, La prueba en el proceso civil, Madrid, Civitas, 2002, pp. 66-67, afirma que la declaración de notoriedad debe hacerse en el momento de proponerse la prueba.

${ }^{26}$ En ese sentido se pronuncian M. Villagómez CeBrián, La nueva Ley de Enjuiciamiento Civil, Madrid, Tecnos, 2000, p. 30, y V. Moreno Catena, «Art. 281. Objeto y necesidad de la prueba», en F. Escribano Mora (coord.), El proceso civil. Doctrina, jurisprudencia y formularios, vol. III, Valencia, Tirant lo Blanch, 2001, p. 2197.

${ }_{27}$ Me reconozco deudor de J. F. Garnica Martín, «La delimitación...», op. cit., pp. 58-59. 
riencia en las que pretenden asentar las presunciones de hombre de las que quieran valerse (con base en el art. 386 LEC). En segundo lugar, y creo que este argumento es más determinante que el anterior, las máximas de experiencia que sí se expresan son las especializadas y se contienen - me atrevería a decir que siempre- en los dictámenes periciales, cuya impugnación es cosa del trámite procesal comprendido en el apartado 2..$^{\circ}$ del art. 427 LEC. Por lo dicho, me reitero en mi impresión inicial. Considero improbable que se haya echado mano del trámite en ningún supuesto con el objeto de fijar las máximas de experiencia pacíficas y controvertidas.

Mayores reservas me suscita la posibilidad de que la redacción del art. 428 LEC permita determinar la existencia o la ausencia de controversia jurídica. Si nos atenemos a la pura literalidad del precepto, es llano que no cabe tal actividad delimitadora ${ }^{28}$. Por otra parte, debo reconocer que la redacción del art. 414 LEC abre la puerta a incluir el objeto y los extremos de derecho ${ }^{29}$. Frente a esto último bien podría argüirse el carácter de norma especial del art. 428.1 LEC con respecto al más genérico art. $414^{30}$. En otro orden de ideas, considero que vislumbrar si la fundamentación jurídica sostenida por un litigante es aceptada o cuestionada de adverso se desprende de los escritos rectores - y de las eventuales alegaciones orales- con mayor facilidad que los propios hechos. Porque debe tenerse bien presente que no se trataría — con ocasión de este trámite- de que las partes aclarasen sus afirmaciones de índole jurídico-material, sino de precisar si la invocación de una norma o la alusión a cierta doctrina jurisprudencial que efectúa una parte la comparte o la discute la adversa. Pero, de todos los argumentos, tengo para mí que el más importante es el que apunta a la finalidad a la que obedece el art. 428 LEC, que no es otra que facilitar el juicio de admisión de prueba - que acontece acto seguido- y, en particular, la pertinencia de la propuesta (ex art. 283.1 LEC).

Cuestión distinta es, a mi juicio, que el juzgador apreciare que la calificación jurídica otorgada a unos hechos por las partes fuera errada y se lo

${ }^{28}$ Y como entiende M. R. GutIÉRREZ SANZ, «La audiencia...», op. cit., p. 402, si no se la nombra por algo será.

${ }^{29}$ Tal y como advierten E. Rodríguez Achútegui, «Art. 428...», op. cit., p. 2637, y J. Arsuaga Cortázar, «Art. 428...», op. cit., p. 2049. Para el primero son dos los argumentos que cabe esgrimir a favor de la extensión de la actividad delimitadora a la controversia jurídica: i) no sólo son los hechos los que configuran la causa de pedir, sino que también resulta de todo punto relevante el enfoque jurídico; ii) en la redacción del art. 414.1 LEC se menciona expresamente como contenido de la función delimitadora la controversia jurídica, además de la fáctica.

${ }^{30}$ J. Arsuaga CoRTÁzAR, «Art. 428...», op. cit., p. 2049. 
expresase a las partes con el propósito de advertirles que se apartará de la misma. En primer lugar, considero que esto sería una cosa completamente distinta a la fijación de la controversia, por muy jurídica que ésta fuese. En segundo lugar, sencillamente no podría hacer tal cosa por prohibírselo el principio dispositivo (ex art. 216.1 LEC) y por ser muy restringida la amplitud con que debe entenderse el principio iura novit curia en nuestro ordenamiento procesal civil ${ }^{31}$. Otra cosa complemente diferente, y que amerita una matización, es la determinación de controversia en torno al Derecho extranjero o al Derecho consuetudinario que hayan podido ser invocados por una parte y que sí precisan de prueba en caso de ser discutida su aplicabilidad, contenido o vigencia ${ }^{32}$.

\section{III. ¿QUÉ QUEDA FUERA DEL ÁMBITO OBJETIVO DEL ART. 428 LEC?}

Sin ningún género de duda, la actividad alegatoria, que se ha tenido que llevar a cabo con anterioridad a la aplicación del art. 428 LEC (actividad que, además, no consta en la redacción del precepto) ${ }^{33}$, agotándose la misma en el trámite anterior contenido en el art. 426 LEC $^{34}$.

Lo que, en cambio, ofrece muchas dudas es el momento para posicionarse los litigantes en relación con determinadas alegaciones fácticas. Dejando al margen el supuesto, evidente, del pronunciamiento del demandado (principal o reconvencional) con respecto a lo manifestado por el actor en su escrito rector, que tiene un momento preclusi-

31 Esta cuestión concreta se la plantea M. SERRANO MASIP, «La iniciativa...», op. cit., pp. 193-230, rechazando finalmente la posibilidad esbozada.

32 Sobre la prueba del Derecho extranjero y de la costumbre vid., con abundante aparato bibliográfico, X. ABEL Lluch, Derecho probatorio, Barcelona, Bosch, 2012, pp. 85-106. Vid., asimismo, J. PiCó I JunOY, «La prueba del Derecho extranjero: ¿dónde está el problema?», en J. Picó I Junoy (dir.), Práctica de la prueba del Derecho extranjero, Madrid, La Ley, 2011, pp. 17-42.

33 J. Arsuaga Cortázar, «Art. 428...», op. cit., p. 2049, sostiene, con buen criterio, que si el demandado no contestó tempestivamente a la demanda (principal o reconvencional) no puede ahora introducir hechos diferentes a los alegados por el actor en la demanda [cita la SAP Baleares (Sección 5. ${ }^{a}$ ) de 6 de abril de 2006]. Con carácter general, y como bien tienen dicho J. J. Tasende Calvo y J. A. Varela Agrelo, «Estudio práctico sobre la audiencia previa», Aranzadi civil: revista doctrinal, núm. 1 (2009) p. 2159, en este trámite procesal no cabe efectuar alegación alguna.

34 Cfr. J. Alonso-Cuevillas y Sayrol, La comparecencia preparatoria..., op. cit., p. 295, cuya opinión vertida en tiempos de la ALEC puede ser perfectamente trasladada a la vigente Ley Civil de Ritos. 
vo indiscutible cual es el de la propia contestación ex art. 405.2 LEC, se advierten otras muchas alegaciones factuales para las que no se contempla expresamente un trámite procesal, oral o escrito, que le permita a la contraparte manifestarse acerca de si las admite o las niega. Así, por ejemplo, nada se dice de la postura del demandante con respecto a lo respondido por el demandado, fuera del caso, claro está, que este último se limite a negar las aseveraciones del accionante ${ }^{35}$ o que este último efectúe alegaciones complementarias. En este último supuesto se da por sentado que este movimiento dialéctico implica el asentimiento con respecto a los hechos nuevos aducidos por el demandado en su contestación. Luego están las oportunidades alegatorias que se regulan en el art. 426 LEC. Con respecto a éstas se me podría objetar que el momento para posicionarse, oralmente, se sitúa inmediatamente a continuación de su manifestación por quien las introduzca. Y es lógico que así fuera, pero eso no quita que la LEC haya guardado absoluto silencio al respecto $^{36}$. Carecería de sentido posponer el posicionamiento - en especial con respecto a las alegaciones correspondientes a los apartados $1 .^{\circ}$ y $4 .^{\circ}$ del art. 426 LEC- para el trámite del art. 428. Sin embargo, sucede en ocasiones, en la praxis forense, que tal pronunciamiento por la parte contraria a quien realiza la alegación brilla por su ausencia. De aquí que, como un mal menor, quepa admitirse el posicionamiento de las partes, dentro del trámite del art. 428.1 LEC, cuando, en los casos señalados (del actor con respecto a la contestación del demandado y de las alegaciones de los apartados $1 .^{\circ}$ y $4 .^{\circ}$ del art. 426) y por las razones apuntadas, no se haya efectuado anteriormente ${ }^{37}$.

35 Como observa acertadamente M. A. DíEz GARCíA, «Consecuencias...», op. cit., p. 342, el pronunciamiento en la audiencia previa sobre los hechos alegados por el demandado puede ser necesario si en la contestación se introducen nuevos hechos hasta entonces inéditos en la litis. Piénsese en hechos incompatibles con los de la demanda o en la alegación de sucesos con eficacia impeditiva, extintiva o excluyente.

${ }^{36}$ Lo que critica, con razón, a mi juicio, I. Álvarez SACRISTÁn, «Inutilidad práctica de la audiencia previa en el proceso civil», Actualidad jurídica Aranzadi, núm. 759 (2008), p. 10.

37 Comparto plenamente el criterio de J. Alonso-Cuevillas y SaYrol, La comparecencia preparatoria..., op. cit., p. 296, cuando señala que, tras este trámite delimitador, ya no debería subsistir ninguna duda o imprecisión acerca de la postura de las partes con respecto a lo afirmado de contrario sobre hechos. Por su parte, E. RodRíGuez ACHútegui, «Art. 428...», op. cit., p. 2638, considera que el art. 428 LEC constituye el complemento perfecto de los arts. 405.2 y 426.6 LEC, en tanto que momento procesal idóneo para suplir pronunciamientos sobre los hechos que debieron efectuarse anteriormente. 


\section{IV. ¿QUIÉN FIJA LOS HECHOS PACÍFICOS Y LOS CONTROVERTIDOS?}

No resulta sencillo ofrecer una respuesta tajante, al menos a tenor de la confusa redacción legal. La infeliz fórmula «de las partes con el juez» — contenida en el apartado 1. ${ }^{\circ}$ del art. 428 LEC — abona el terreno a que, en la práctica, se proceda de diferentes maneras ${ }^{38}$. En unos casos, el juez asume todo el protagonismo y delimita la controversia fáctica ${ }^{39}-\mathrm{o}$ eso se pretende-, pues, por lo general, lo más que hace es dar lectura al suplico de la demanda o, en el mejor de los casos, realizar un apresurado resumen de las líneas básicas de la controversia ${ }^{40}$, aunque hay que reconocer que en otros pocos supuestos es el propio juez el que delimita perfectamente los hechos controvertidos y no controvertidos. En otros casos, el órgano jurisdiccional asiste impávido a lo que manifiestan las partes ${ }^{41}$, que, lejos de llevar a cabo la confección de una relación exhaustiva de hechos pacíficos y

${ }^{38}$ Critican la redacción legal, entre otros, A. URIarte Cordón, «Sujetos...», op. cit., p. 333, y A. Capilla Casco y J. Sánchez Lozano Velasco, «Patologías...», op. cit., p. 67. En cambio, la ensalza A. Dolado PéREZ, «La posición de las partes respecto a la documentación aportada y la fijación de hechos controvertidos», Cuadernos de Derecho Judicial, núm. 2 (2008), p. 252.

39 Recabando, eso sí, el asentimiento de las partes a su reseña o bien preguntando a cada parte si admite los hechos alegados de contrario, tal y como describe J. ARsuAgA CoRTÁZAR, «Art. 428...», op. cit., p. 2049. Un claro ejemplo de este tipo de práctica se recoge en la SAP Málaga (Sección 6. ${ }^{\text {a) }}$ núm. 32/2014, de 14 de enero (JUR 2014/278260). En este caso, la juzgadora fijó ella sola los hechos pacíficos y controvertidos, sin dejar que los letrados intervinieran lo más mínimo. La superioridad jerárquica decretó la nulidad de actuaciones y ordenó la retroacción de las actuaciones al momento anterior a la celebración de la audiencia previa.

40 Así lo denuncian A. Capilla Casco y J. Sánchez-Lozano Velasco, «Patologías...», op. cit., p. 67. También lo reconoce la SAP Cádiz (Sección 2. a) núm. 152/2014, de 1 de junio, fundamento jurídico . $^{\circ}$ (JUR 2011/326725).

${ }^{41}$ Cuando me refiero a las partes, pienso en las defensas técnicas porque no cabe en el ordinario que las partes puedan actuar sin abogado (ex art. 31 LEC). Además, como sostiene J. Arsuaga Cortázar, «Art. 428...», op. cit., p. 2048, es lo lógico atendido el conocimiento jurídico exigido para el óptimo desarrollo del trámite. En la misma línea, J. M. F. PAZ Rubio, J. Achaerandio Guijarro, A. de Andrés Herrero, A. V. Illescas Rus, L. Puente Segura y C. Salgado Carrero, Ley de Enjuiciamiento Civil comentada y con jurisprudencia, Madrid, La Ley, 2000, p. 623. De manera diferente, E. RodRíguez AchúTEGUI, «Art. 428...», op. cit., p. 2638, subraya que deben ser las propias partes, y no tanto sus asesores, quienes intervengan en la actividad delimitadora, habida cuenta que son ellos los que más y mejor conocen los hechos litigiosos. Por su parte, X. ABEL LluCH, «La función delimitadora de la audiencia previa», Revista vasca de Derecho procesal y arbitraje, vol. 25, núm. 1 (2013), pp. 18-19, expone los argumentos que podrían justificar la chocante mención a las partes en la redacción del art. 428.1 LEC. 
controvertidos, se pierden en inútiles ejercicios de síntesis de lo alegado o visitan con fruición el petitum o los puntos álgidos de sus respectivos escritos rectores ${ }^{42}$. Sea como fuere, no acaba de estar claro a quién le corresponde efectuar la actividad de fijación a la que se contrae el apartado $1 .^{\circ}$ del art. $428 \mathrm{LEC}^{43}$.

No obstante la ambigua fórmula legal, estimo posible defender que es a las partes, y sólo a ellas, a quien corresponde reseñar los hechos pacíficos y controvertidos ${ }^{44}$. Son varios - y entiendo que sólidos- los argumentos que me permiten llegar a tal conclusión. En primer lugar, estimo relevante que en la redacción legal se anteponga a las partes con respecto al juez, lo que les atribuye, sin duda, un mayor protagonismo ${ }^{45}$. En segundo lugar, qué duda cabe que son los litigantes - y, particularmente, sus defensas técnicas- los que mejor conocen los escritos rectores, de modo que les ha de resultar más sencillo a ellos efectuar la delimitación ${ }^{46}$. Es más, es a ellos a quien principalmente conviene que quede bien sentado qué afirmaciones son controvertidas, habida cuenta las consecuencias que ello acarreará de cara al mayor o menor esfuerzo probatorio a realizar. En tercer lugar, no se puede perder de vista que en la redacción de la norma que disciplina el acto del juicio en el verbal —me refiero al art. 443.3 LEC - se dice claramente que «se dará la palabra a las partes para [...] fijar los hechos sobre los que exista contradicción». En cuarto lugar, rige en todo el proceso el principio dispositivo de las partes

${ }^{42}$ Cfr. I. Állarez Sacristán, «Inutilidad práctica...», op. cit., pp. 9-10.

${ }^{43}$ Una buena muestra de tal confusión la ofrecen J. HOYA COROMINA, «Art. 428...», op. cit., p. 1904, y J. J. Tasende Calvo y J. A. Varela Agrelo, «Estudio práctico...», op. cit., p. 2158, para quienes vendría a resultar indiferente si el trámite lo desarrolla el juez o las partes.

${ }_{44}$ A favor, S. Barona VIlar, «Art. 428...», op. cit., p. 3202, y J. Banacloche PalaO, «Las otras finalidades de la audiencia previa al juicio», en A. DE LA Oliva SANTOS (coord.), El tratamiento de las cuestiones procesales y la audiencia previa al juicio en la Ley de Enjuiciamiento Civil, 2. ${ }^{a}$ ed., Madrid, Civitas, 2009, p. 318. En contra, y entre otros, dejándolo en manos del juez, X. Abel Lluch, «La audiencia previa...», op. cit., p. 338; A. URiarte Cordón, «Sujetos...», op. cit., p. 333, y J. ArsuAGA CoRTÁzAR, «Art. 428...», op. cit., pp. 2048-2049. Adopta una postura intermedia E. RodRíGUEZ AchÚtEGUI, «Art. 428...», op. cit., p. 2638, quien atribuye esta función a las partes con carácter principal, mientras que reconoce una intervención subsidiaria al tribunal.

${ }^{45}$ A. URIARTE CORDÓN, «Sujetos...», op. cit., p. 333, sostiene la tesis contraria —el protagonismo lo debería tener el juez-, critica el orden de introducción de los protagonistas de la controversia en el tenor literal de la norma concernida.

${ }^{46}$ A favor, A. Bonet Navarro, La nueva comparecencia..., op. cit., p. 117. Lo que no quita que el juez deba acudir a la audiencia previa conociendo el asunto, como exige A. URIarte Cordón, «Sujetos...», op. cit., p. 333. Práctica muy sana, desde luego, que ya se reclamaba en tiempos de la ALEC, como se desprende de las palabras de A. BONET NAVARRO, La nueva comparecencia..., op. cit., p. 114. 
(art. 19 LEC), con una mínima intervención judicial durante el desarrollo del primero.

En definitiva, son las partes las que tiene la obligación de tomar la iniciativa del trámite y deben ser ellas las que manifiesten qué hechos reputan pacíficos y qué hechos consideran controvertidos. En ningún caso el juzgador. Dicho esto, me aventuro a interpretar que, en realidad, la norma toma una perspectiva más alejada, de conjunto para ser exactos. No se refiere con la expresión «las partes con el juez» al concreto y puntual acto de reseñar los hechos, clasificándolos como pacíficos o como controvertidos, sino que alude a la actividad de fijación como conjunto, la cual incluye un segundo momento que suele pasar inadvertido. Me refiero a la eventual disputa que pueda surgir entre los contendientes a la hora de asignar un concreto hecho a una categoría o a otra. Momento en el que - y esto es importante- quien cobra el protagonismo es el juez, por cuanto será él quien tenga que dirimir esta puntual disputa. Así las cosas, la sincrética fórmula legal, desafortunada si se considera exclusivamente desde la perspectiva de a quién corresponda la iniciativa de enunciar hechos - pacíficos y controvertidos-, merece un juicio menos severo si se considera desde el punto de vista expuesto. Esto es, si se atiende a los dos momentos que encierra la actividad delimitadora. El primero, en el que son las partes, de forma exclusiva, quienes deben tomar la iniciativa y manifestarse. El segundo, en el que, en cambio, el juzgador acapara todo el protagonismo.

Finalmente, considero que la delimitación de hechos es una verdadera carga procesal para las partes, cuyas defensas técnicas deben acudir al acto de celebración de la audiencia previa debidamente preparadas. En la práctica de los tribunales, en más de una ocasión se ha podido advertir la actuación de un letrado «en sustitución» de su compañero, quien, desconociendo por completo el contenido del pleito, se ha limitado a llevar consigo el escrito de proposición de prueba, lo que constituye una actuación, cuanto menos, temeraria y contraria a la buena fe procesal frente a aquella parte que sí acude con la audiencia previa debidamente preparada ${ }^{47}$.

Por supuesto, cualquier práctica procesal que se aparte de lo que — según la tesis aquí defendida- establece la Ley debe ser denunciada en el acto, de forma que se provoque un pronunciamiento judicial formal —que, a su vez, active el procedimiento del art. 210.2 LEC—, amén

${ }^{47}$ En cuanto a la buena fe procesal vid., por todos, J. Picó I Junoy, El principio de la buena fe procesal, 2." ed., Barcelona, Bosch, 2013. 
de que guardar silencio impide poder sostener la queja posteriormente en sede de recursos devolutivos ${ }^{48}$.

\section{EL DESARROLLO DE LA ACTIVIDAD DELIMITADORA}

Me permito un breve excurso inicial para abordar una cuestión que me parece obligada y que no se puede dejar para más adelante. Cabe preguntarse qué sucede si el juez prescinde del trámite ${ }^{49}$. Si directamente transita de un trámite anterior al trance de la proposición y admisión de prueba. Quizá fuese más correcto enfocarlo desde el prisma de qué puedan hacer las partes que, interesadas - como deberían estar - por realizar el trámite de delimitación, observan cómo el juzgador lo omite sin más. A este respecto entiendo - a falta de un precepto específico que ofrezca un remedio efectivo — que la parte —o las partes— deberá solicitar —en el sentido específico de peticionar; no bastará con comentar o sugerir- al órgano jurisdiccional que se detenga en este punto y se aborde la actividad delimitadora del art. 428.1 LEC, atendido que dicho trámite no se contempla en la Ley como facultativo. Es más, en el «programa de la audiencia previa» ${ }^{50}$, recogido en el art. 414.1.II LEC, se contempla específicamente el cometido delimitador como un paso a dar indefectiblemente. Además, las normas procesales son de inexcusable observancia para el tribunal en virtud de lo dispuesto en el art. 1 de la Ley Civil de Ritos. Quizá —y según se aprecie la reacción del juez- baste con lo anterior para que dé marcha atrás o, por lo menos, no siga adelante sin pasar por el trámite concernido. A mayor abundamiento, siempre se podría aducir que, desde la perspectiva de la legalidad ordinaria, sin efectuar la actividad delimitadora resulta imposible que el tribunal, posteriormente, repudie un medio de prueba por impertinente (ex art. 283.1 LEC). Desde una perspectiva constitucional, dejar de fijar la controversia puede conllevar, en último término, una vulneración del derecho a la prueba del art. 24.2 CE. Sea como fuere, frente a tal manifestación, el juzgador deberá pronunciarse oralmente en el mismo

${ }^{48}$ Cfr. SAP Madrid (Sección 21.a) núm. 108/2005, de 18 de enero, fundamento jurídico 5. ${ }^{\circ}$ (AC 2005/497).

${ }^{49}$ No se trata de una circunstancia extraordinaria, como advierten X. ABEL LLUCH, «La función delimitadora...», op. cit., p. 3, y A. Capilla Casco y J. Sánchez-Lozano Velasco, «Patologías...», op. cit., p. 67.

${ }^{50}$ Expresión tomada de V. FAIRÉn GuILlén, La audiencia previa. Consideraciones teórico-prácticas (comentarios a los arts. 414 a 430 de la Ley de Enjuiciamiento Civil de 7 de enero del año 2000), Madrid, Civitas, 2000, pp. 59-64. 
momento acerca de si manda acometer el trámite o persiste en orillarlo. Si la decisión adoptada expresamente fuese esta última, entonces bastaría con guardar silencio - lo que no quita que no se pueda verbalizar la disconformidad- para que la resolución oral no ganase firmeza y el juez se viese en la obligación de ponerla por escrito al término de la audiencia previa, para después notificarla a las partes y que la disconforme pueda recurrirla oportunamente. En definitiva, no se ha dicho otra cosa que no sea lo recogido expresamente en el art. 210.2 LEC.

Retomando el hilo principal de la exposición, el desarrollo del trámite debe comenzar con la cesión del uso de la palabra a la parte actora para que manifieste los que considera hechos pacíficos y controvertidos. He aquí que conviene efectuar tres importantes precisiones. La primera es que debe tomar la palabra una sola de las partes — por cada turnopor una obvia cuestión de orden y claridad. La segunda es que si comienza la actora es porque, de ordinario, el componente fáctico de su demanda es sustancialmente superior al de la demandada. La tercera tiene que ver con el contenido de su exposición. Considero que conviene ceñirse a la letra de la Ley. El apartado 1. ${ }^{\circ}$ del art. 428 LEC especifica que deben reseñarse tanto los hechos pacíficos como los controvertidos, y no únicamente estos últimos. Otra cosa es que luego se impongan malas prácticas, como lo es la de limitarse a formular los que se consideran controvertidos con la excusa de que lo no discutido debe reputarse pacífico. Eso sería así si no cupiese la posibilidad, como ya veremos seguidamente, de que el actor señalase como pacíficas aquellas afirmaciones de hecho respecto de las cuales el demandado ha guardado silencio o ha evadido su posicionamiento (ex art. 405.2 in fine LEC).

Considero muy recomendable que las partes acudiesen a la audiencia previa con dos listados escritos de hechos. Un listado debería incorporar los hechos pacíficos y el otro los controvertidos. De dichos listados debería facilitarse una copia tanto al juez como a la parte contraria. Opino que no sería ocioso que dichos listados quedasen incorporados a los autos, con independencia de las adiciones que resulte necesario efectuar atendido el ejercicio dialéctico oral que pueda acontecer en los concretos subtrámites del art. 426.1 y 4 LEC. No obstante la aportación de los listados, estimo imprescindible que, sin prisas y de forma inteligible, se verbalice el contenido de ambas listas a fin y efecto de que queden bien recogidos en la grabación audiovisual.

Además, estimo muy recomendable que la parte actora, cuando delimite los hechos controvertidos y los no controvertidos, haga una expre- 
sa mención al escrito de contestación del demandado. Así, por ejemplo, manifestar que considera que un determinado hecho no es controvertido en tanto en cuanto se halla expresamente reconocido por parte del demandado en el párrafo tal de la página cual del escrito de contestación a la demanda. Entendemos que dicho proceder ayudaría al juzgador (y a la adversa) en el correcto desarrollo del trámite del art. 428 LEC.

Una vez el actor haya concluido su exposición, el juez debe conceder el uso de la palabra al demandado para que, con respecto a los hechos que haya alegado en la contestación o de forma oral en el curso de la dialéctica de la audiencia previa (insisto, casi exclusivamente en el marco de los apartados $1 .^{\circ}$ y $4 .^{\circ}$ del art. 426 LEC) — de ordinario, hechos antagónicos o antitéticos con los afirmados de contrario, hechos-base de presunciones o hechos sobre los que se asiente una excepción material—, manifieste si la demandante se ha conformado o los ha disputado expresa y concretamente. Valga lo dicho antes para el actor: me refiero a la conveniencia de traer hechas las listas de hechos a la audiencia previa y también de traer consigo preparadas las referencias de las páginas del escrito de demanda y de la contestación donde constan exactamente delimitados los hechos controvertidos y no controvertidos.

Sin retirarle el uso de la palabra al demandado, el juez debería preguntarle si se muestra conforme con la relación de hechos de ambas clases que ha efectuado el demandante previamente y, en caso de discrepar, que concrete de qué facta se trata y, sobre todo, por qué estima errónea la asignación de hechos (a una u otra categoría) que haya efectuado el actor. Concluido el parlamento del demandado, debería retornarse el uso de la palabra al demandante para que argumente lo que tenga por conveniente sobre los motivos de disconformidad del demandado con la distribución de los hechos. Sin retirarle el uso de la palabra, convendría que, acto seguido, se posicionara sobre los listados propuestos por el demandado. Finalmente, debería concederse un último turno de palabra para que la parte pasiva pudiera argumentar, a fin y efecto de sostener la distribución como pacíficos o controvertidos de sus propios hechos (hechos antagónicos o antitéticos con los afirmados de contrario, hechos-base de presunciones o hechos sobre los que se asiente una excepción material).

Aun cuando de primeras pudiera dar otra sensación, este entrecruce dialéctico no entraña especial dificultad por cuanto se trata de la concatenación de actos de habla naturales, intuitivos, que se enmarcan en un trámite procesal oral. Tampoco pretendo encorsetar dicha dialéctica en un 
número limitado de movimientos ${ }^{51}$. Sencillamente, me he limitado a los tres más básicos: afirmación de los hechos que se consideran pacíficos y controvertidos por una parte; expresión de discrepancias por la adversa (amén que relación del carácter de conformes o disputados que esta última haya afirmado en el momento correspondiente), y, por último, oportunidad de la parte inicial para defender su propuesta de hechos pacíficos y controvertidos y rebatir las objeciones de la contraria. Insisto, este movimiento dialéctico debe ser tan rico, amplio y prolongado como lo amerite la carga de hechos afirmados por las partes en el caso concreto. Y añado que no ha de tomarse como un contratiempo que las partes puedan solicitar del juez que les conceda unos minutos para consultar los autos o, incluso, para interrumpir la vista por un breve lapso de tiempo a tal efecto.

Sugiero que las discrepancias con la configuración de los listados - que no será de todo su contenido, obviamente- se justifiquen, remitiendo las partes a los extremos de los escritos rectores donde consideren que sí se ha dado respuesta o para constatar cuál sea la respuesta que efectivamente se dio. Esto me parece especialmente necesario para los casos en que una parte ha efectuado una afirmación de hecho y considera que la adversa ha guardado silencio o ha evadido la respuesta, dirigiendo su discurso por otros derroteros. En definitiva, me refiero a los supuestos en que una de las partes quiera que se aplique aquí y ahora el contenido del art. 405.2 in fine LEC. Me parece relevante que la parte a la que se le imputa una falta de pronunciamiento pueda evidenciar, con la designación de la página y del párrafo correspondientes, que sí se ha posicionado claramente, dando satisfacción a la exigencia del apartado $2 .^{\circ}$ de dicho art. 405 LEC.

Es éste también un buen momento para que las partes aduzcan sus argumentos en relación con el pretendido carácter notorio de un hecho, cuando sea el caso de alguno de los afirmados por los litigantes. Incluso me atrevería a decir que podría constituir una inmejorable oportunidad de que se elucidase el carácter de común o de especializada de una máxima de experiencia.

Cierro este epígrafe, por una cuestión de orden y claridad de la exposición, aprovechando que doy por concluido el análisis de este primer momento del trámite delimitador del apartado $1 .^{\circ}$ del art. 428 LEC. Pero quiero alzaprimar que dicha actividad no ha acabado todavía. Es más,

${ }^{51}$ De hecho, cuantos más, mejor, si con ello las partes se fuerzan recíprocamente a admitir el mayor número de afirmaciones de hecho posibles, como apuntaba J. AlonsoCuevillas y SAYrol, La comparecencia preparatoria..., op. cit., pp. 297 y 298. 
resta aun una segunda parte cuanto menos tan relevante como la primera, como es la actividad decisoria del juez.

\section{LA INTERVENCIÓN DECISORA DEL JUEZ EN EL CASO DE REGISTRARSE DISCREPANCIAS ENTRE LAS PARTES}

Hasta este momento, el papel del tribunal puede calificarse de discreto, si bien esencial, pues lo que ha hecho hasta entonces es el ejercicio de su función -importantísima- de dirección de los debates del art. 186 LEC, concretada a una acto procesal oral específico. No me cabe la menor duda de que la dinámica dialéctica anteriormente expuesta requiere de un juez sumamente atento y activo $^{52}$, que vaya dirigiendo el debate sin inmiscuirse en el mismo y apreciando los argumentos de cada uno de los letrados. Así las cosas, me resisto a atribuirle al órgano jurisdiccional la condición de convidado de piedra. Máxime cuando, como ahora se verá, es muy posible que en el segundo momento del trámite deba intervenir para adoptar una decisión para la que precisará estar bien pertrechado de argumentos ${ }^{53}$.

Comienzo el estudio de este segundo momento del trámite delimitador sosteniendo su carácter eventual. Aunque se me antoja infrecuente, puede acontecer que las partes contendientes coincidan en la delimitación de los hechos y no se registre la menor disputa a este respecto. En tal caso, la relación de hechos pacíficos y controvertidos deviene definitiva, de forma tal que los primeros deberán constar tal cual en un apartado específico de la sentencia ${ }^{54}$. En cuanto a los segundos, su constancia escrita —además de su registro en el soporte audiovisual- debería constituir un inmejorable apoyo para el juez a la hora de emitir el juicio de admisión de prueba y de cribar las preguntas impertinentes en el acto del juicio, entre otras cosas.

Por el contrario, cuando se ponga de manifiesto la efectiva existencia de desencuentro entre las partes a la hora de considerar una determinada

52 Como bien afirma J. F. ETXEBERRIa GuRIDI, «Consideraciones acerca de la audiencia previa al juicio en la nueva LEC (y II)», Diario La Ley, Sección Doctrina, ref. D-201, t. 6, 2001, p. 2.

${ }_{53}$ También se defiende que el juez debe intervenir para conseguir que las partes convengan sobre el carácter pacífico de ciertos hechos y para solicitarles que califiquen una determinada afirmación fáctica que ninguno de los litigantes haya mencionado. Estos cometidos del tribunal los propone E. Rodríguez AchúteguI, «Art. 428...», op. cit., pp. 2638-2639.

54 Apunta agudamente J. Damián Moreno, «La audiencia previa...», op. cit., p. 103, que la actividad de delimitación debe conducir a una decisión del juez acerca de los hechos sobre los que exista disconformidad y conformidad. 
afirmación de hecho como pacífica o controvertida, o como hecho notorio, o al punto de determinar si una máxima de experiencia es aceptada o cuestionada, se requiere indefectiblemente un pronunciamiento del juez ${ }^{55}$. La polémica no puede quedar abierta sine die, porque los efectos nocivos de postergar su resolución se padecerán inmediatamente cuando llegue el turno del juicio de admisión de prueba. Por tanto, el tribunal debe zanjar el debate con una resolución ${ }^{56}$. Y lo debe hacer de manera inmediata, de forma oral inexcusablemente, tal y como manda el art. 210.1 $\mathrm{LEC}^{57}$, sin que la propia norma autorice, en modo alguno, el diferimiento de la cuestión para su resolución posterior de forma escrita tras la conclusión de la audiencia previa. Dicha resolución — sigo moviéndome en los estrictos términos de la redacción del precitado precepto legal - deberá contener una disposición y su correspondiente motivación. La primera deberá consistir en un pronunciamiento del tipo «considero tal afirmación de hecho equis pacífica o controvertida, o tal hecho como notorio o como carente de notoriedad, o tal máxima de experiencia como pacífica o controvertida». Seguidamente, deberá aducir las razones que respaldan su decisión, sin que su justificación deba ser sucinta, sino tan amplia y abundante como sea preciso, habida cuenta que lo que manifieste se registra en un soporte audiovisual y no es cosa ya de que el letrado de la Administración de Justicia deba tomar nota manuscrita deprisa y corriendo. Asimismo, estimo que, por simplicidad, cada desencuentro concreto con respecto al carácter pacífico o controvertido de un hecho o máxima de experiencia, o sobre la notoriedad o no de un factum, requiere una resolución individual.

Pronunciado el parecer del juez de forma oral con arreglo a lo dispuesto en el art. 210.1 LEC, tanto el silencio como la manifestación expresa de disconformidad impedirán que la resolución gane firmeza y vincule al propio tribunal en lo que resta de proceso ${ }^{58}$. Y no sólo eso. Cuando concluya

55 J. M. F. Paz Rubio, J. Achaerandio Guijarro, A. de Andrés Herrero, A. V. Illescas Rus, L. Puente Segura y C. Salgado Carrero, Ley de Enjuiciamiento Civil comentada..., op. cit., p. 623, afirman que la norma no concede facultades decisoras al tribunal a este respecto.

56 En el caso de la SAP Segovia (Sección 1.a) núm. 108/2014, de 30 de junio, fundamento jurídico 2..$^{\circ}$ (JUR 2014/222117), el actor se empecinó en sostener que no existía controversia fáctica y, ante esto, el juez zanjó la disputa sentando que sí había tal y los términos de la misma.

57 Sobre el particular me remito a C. DE Miranda VÁzQuez en su trabajo, todavía inédito, «Las resoluciones orales en el proceso civil».

58 Con dudoso acierto procesal, la SAP Huelva (Sección 2. a) núm. 128/2014, de 25 de junio, fundamento jurídico $2 .^{\circ}$ (JUR 2014/256293), sostiene que se adoptó una decisión en torno a los hechos pacíficos y controvertidos, y que la misma fue consentida por los litigantes al no ser impugnada ni contrariada expresamente por la recurrente en apelación. 
la audiencia previa y sin que la Ley contemple un plazo terminante al respecto, el juzgador deberá redactar la resolución oral debidamente y notificársela a las partes, disponiendo entonces de cinco días para interponer recurso de reposición - con arreglo a los arts. 452 y ss. LEC-, a contar desde el día mismo de la notificación, por precaución. Por consiguiente, no deberá admitirse ni la interposición de un recurso de reposición oral in actu ni el empleo de la fórmula de la «protesta, a los efectos de la segunda instancia» (puesto que la reposición oral y la subsiguiente protesta sólo se prevé para el momento procesal de admisión o inadmisión de las pruebas propuestas por las partes, ex art. 285.2 LEC). El cauce procesal, perfectamente trazado en la LEC, debe andarse sin que valgan atajos o apaños, dicho, claro está, desde una perspectiva de lege lata.

De lege ferenda, en cambio, la solución legal me parece manifiestamente mejorable. Y ello por las muchas y enjundiosas complicaciones que pueden resultar de un cambio de opinión del órgano jurisdiccional a resultas del recurso de reposición interpuesto por una de las partes frente a la resolución oral debidamente redactada. Si algo que se estimó pacífico se torna en controvertido, la proposición de prueba deviene insuficiente y se corre el grave riesgo de vulnerar el derecho a la prueba de la parte. La solución, en tal caso, debería pasar, a mi juicio, porque el juez repusiera su resolución oral, ahora debidamente escrita, y anular las actuaciones y retrotraerlas hasta el momento mismo de proponer y admitir prueba. Pero este movimiento de retrocesión procesal presenta dos serios inconvenientes. El primero es que la anulación parcial de actuaciones se lleva por medio a la resolución oral debidamente escrita, lo cual me parece una cuestión menor, pues, en realidad, no se trata de una segunda resolución, sino de la única — verbal - puesta por escrito. Lo que me parece inevitable es que se tendrá que señalar una nueva audiencia previa - $\mathrm{O}$ la reapertura de la primera- a los solos efectos de que el juez manifieste con qué carácter quedan el hecho o la máxima de experiencia disputados — sin posibilidad de recurrir la adversa—, dando paso al trámite del art. 429.1 LEC. Lo suyo sería que se limitasen las partes a proponer la prueba exclusivamente con respecto al hecho que se ha tornado controvertido. Sin embargo, no se me oculta que la nulidad parcial no permite, a mi juicio, una eliminación selectiva de los contenidos de un determinado trámite. Y eso significa que la repetición íntegra del trámite de proposición y admisión de prueba puede comportar que las partes aprovechen para «mejorar» sus planteamientos al respecto, lo cual estimo un despropósito. 
Otra solución, menos enojosa, podría consistir en que la propia resolución que estima el recurso de reposición disponga lo necesario para administrar adecuadamente el cambio de signo de un hecho o máxima de experiencia. Si un hecho controvertido pasara a gozar de la condición de pacífico, únicamente cabría que el juez invitase a la parte que propuso prueba a que desistiese de ella, pues sólo podrá atenerse en la sentencia al carácter pacífico del hecho o máxima de experiencia. Si lo que sucede es justamente lo contrario (lo pacífico se transmuta en controvertido), quizá fuese suficiente con que se tramitase por escrito la proposición de prueba y se resolviese de igual forma. Al menos, si sólo es una la mutación operada. Si son varias, estimo más sensato que se señalase una vista a estos solos efectos.

Es bien visible, me parece, la imperiosa necesidad de que se reforme este aspecto de la norma, de modo que, a la par de lo que acontece con el juicio de admisión de prueba (ex art. 285 LEC), frente a la resolución oral en materia de delimitación de la controversia fáctica cupiese interponer, sin solución de continuidad, recurso de reposición verbal a resolverse de forma inmediata. El régimen presente resulta infeliz, lo que explica que en la práctica las partes guarden silencio y se aquieten ante la decisión final del juez a este respecto.

\section{BREVE EXCURSO: LA NECESIDAD DE QUE EL ART. 405.2 IN FINE LEC SE APLIQUE EN ESTE MOMENTO PROCESAL}

A mi modo de ver, la más que acertada previsión legal contenida en el art. 405.2 in fine como mecanismo disuasorio de conductas que entorpecen, cuando no inhiben, la utilidad del fluir dialéctico sólo presenta un inconveniente, pero es de tal envergadura que inutiliza dicho mecanismo ${ }^{59}$. Me refiero a la ausencia de la menor precisión acerca del momento en que el juez — que «debería» en lugar de «podría» ${ }^{60}$ - aplique la norma que ahora nos ocupa.

Tradicionalmente se ha considerado que, a falta de otra indicación legal, será en la sentencia cuando deba el juez aplicar el precepto. Sin embargo,

\footnotetext{
59 Comparto plenamente la visión pesimista que ofrece F. OrTEGo Pérez en su trabajo «Los escritos de alegaciones», en J. Picó I Junoy, Presente y futuro del proceso civil, Barcelona, Bosch, 1998, p. 213.

${ }^{60}$ El tenor literal de la norma se pronuncia en términos de «facultad» judicial y no de «obligación», como apostilla la SAP León de 20 de enero de 2004 (JUR 2004/53020).
} 
entonces ya es demasiado tarde. La parte que vertió la afirmación en el proceso, pese al silencio o a la postura evasiva de la contraria, deberá articular prueba, no fuera cosa que luego en la sentencia no se aplicase la consecuencia del art. 405.2 in fine LEC, por descuido o por no considerarlo procedente el juzgador. Es cierto que dicho litigante puede albergar la esperanza de que, quizás, en segunda instancia se le dé la razón y se dé por admitido el hecho frente al que hubo silencio o evasión de respuesta. Pero eso es mucho confiar y supone asumir un riesgo excesivamente elevado.

También se ha defendido, con respecto a dicha carencia del art. 405.2 in fine LEC, contando, eso sí, con menor respaldo, que la Ley ha introducido a lo largo de su articulado otros mecanismos que permiten al tribunal apreciar la conducta de las partes en relación con su deber de posicionamiento y, más concretamente, se ha querido ver en el art. 426.6 LEC la solución ${ }^{61}$. Sin embargo, y según he razonado anteriormente, este último precepto ni está diseñado para la delimitación del objeto del proceso ni tampoco para que el juzgador aplique la consecuencia prevista en el art. 405.2 LEC para la omisión de pronunciamiento del demandado.

Efectuadas las anteriores consideraciones, estimo oportuno romper una lanza en favor de la tesis de la aplicación del efecto del art. 405.2 in fine en este preciso momento procesal ${ }^{62}$. No en vano, el aludido mecanismo opera como una suerte de sanción para el litigante que deja de posicionarse - directa o indirectamente- con respecto a las afirmaciones de hecho de la parte contraria. La penalización consiste en que el juez las tenga por admitidas y, por ende, la consecuencia inmediata es que devienen pacíficas y exentas de prueba. Así las cosas, es el trámite del art. 428.1 LEC el escenario más apropiado —el único, me atrevería a decir- para que una parte pretenda aplicar dicha sanción — si se me permite la expresión, un tanto severa-, reputando determinado hecho como pacífico, y la otra eventualmente lo cuestione ${ }^{63}$. Otra solución, y desde luego la actual,

${ }^{61}$ Cfr. J. Damián Moreno, «La audiencia previa...», op. cit., p. 103, e ÍD., «Art. 428. Fijación de los hechos controvertidos y posible sentencia inmediata», en A. M. LORCA NAVARRETE (dir.) y V. Guilarte GutiérRez (coord.), Comentarios a la nueva Ley de Enjuiciamiento Civil, t. I, Valladolid, Lex Nova, 2000, p. 2154. También parece ser la postura de I. TAPIA FERNÁNDEZ, «Art. 428...», op. cit., pp. 1798-1799.

${ }^{62}$ Sostenía esta postura, ya en tiempos de la ALEC, J. Alonso-Cuevillas y Sayrol, La comparecencia preparatoria..., op. cit., pp. 298 y 299. Con respecto a la vigente LEC vid. J. BANAClOCHE PALAO, «Art. 428...», op. cit., p. 722.

${ }^{63}$ Lo que es completamente diferente es que el juez «interrogue» al demandado para extraerle un posicionamiento sobre las afirmaciones de la actora, a medio camino entre la contestación a la demanda y la confesión de hechos, como expone con acierto, a mi jui- 
prácticamente vacía de contenido la previsión legal del art. 405.2 in fine, que deviene inoperante en la práctica ${ }^{64}$.

\section{UNA APUESTA POR LA EFICIENCIA PROCESAL: LA RELACIÓN ÚNICA DE HECHOS}

Sugirió en su momento, con mucho tino, el profesor Alonso-Cuevillas que, superado el trámite del apartado 1. ${ }^{\circ}$ del art. 428 LEC, debería unificarse toda la información fáctica en una suerte de documento «oficial» - por supuesto, que quedase unido a los autos- en el que se recogiesen todos los hechos pacíficos y los controvertidos, con su debida separación. $\mathrm{Y}$ con respecto a estos últimos, podría señalarse también a qué parte le corresponde la carga de su prueba ${ }^{65}$. Una vez confeccionado - y distribuido- este documento único, con la totalidad de las alegaciones fácticas de las partes en litigio, podría prescindirse de los escritos rectores simplificándose la gestión procesal ${ }^{66}$.

Este documento tan útil, a mi modo de ver, tendría - para ir bienque materializarse al término del propio trámite de delimitación de la controversia fáctica. Su provecho se dejaría sentir ya en la propia audiencia previa, en el trámite siguiente de proposición y admisión de prueba ${ }^{67}$. Revestiría especial interés disponer del mismo durante la práctica de la prueba y al tiempo de evacuar las conclusiones en las postrimerías del acto del juicio. Y qué duda cabe que le rendiría un estimable servicio al juez a la hora de dictar sentencia.

Bien es verdad que nos movemos en el terreno de la especulación, porque la implantación de este «documento único de hechos» no cuenta con el menor respaldo normativo y eso le hace un flaco favor porque, de pri-

cio, la SAP Valencia (Sección 1. a) núm. 109/2006, de 14 de marzo, fundamento jurídico 2. ${ }^{\circ}$ (AC 2006/1498).

${ }^{64}$ A este respecto, S. Barona VILAR, «Art. 428...», op. cit., p. 3203, sostiene que si la consecuencia del art. 405.2 in fine LEC se deja para la sentencia resulta la «respuesta poco útil a los efectos pretendidos», mientras que si se lleva a cabo en la audiencia previa, la solución sería muchísimo más efectiva.

${ }_{65}$ Así, J. Alonso-Cuevillas y SAYrol, La comparecencia preparatoria..., op. cit., p. 300.

${ }^{66}$ Ibid.,p. 301.

${ }^{67}$ Sostiene J. Damián Moreno, «La audiencia previa...», op. cit., p. 103, que el legislador debería haber obligado al juez a indicar qué hechos entiende admitidos y cuáles no, ya que de otro modo se fuerza indirectamente a las partes a tener que solicitar prueba para todos los hechos, no sea el caso de que luego el tribunal considere controvertido lo que parecía que era pacífico, con la subsiguiente pérdida de oportunidad procesal. 
meras, a los operadores forenses les costaría apreciar sus muchas bondades. Por ello se sugiere, como propuesta de lege ferenda, su integración en el texto normativo procesal civil.

Lo dicho entronca directamente con otro problema, de no menor envergadura, que constituye un quebradero de cabeza especialmente para los letrados. Me refiero a la principal consecuencia que se extrae de la ausencia de un pronunciamiento expreso y definitivo del tribunal acerca del carácter de pacíficos o controvertidos de los hechos del pleito. En el momento presente, y con arreglo a la redacción vigente del art. 428.1 LEC, las partes, «con el juez», relacionan unos y otros hechos, pero nada sale en claro de ahí más que la grabación audiovisual de la audiencia previa. Y puede suceder, desafortunadamente, que un hecho que se consideró pacífico más tarde se repute controvertido - por ejemplo, al tiempo de dictarse la sentencia - y a la inversa. Evidentemente, se podrá denunciar esta alteración con los efectos oportunos. Se me antoja empresa difícil si en la proposición de prueba se acepta la prueba de un hecho pacífico o se rechaza la de uno controvertido, porque habría - me imagino- que interrumpir la audiencia previa (bajo una interpretación forzada del art. 193.1.1. ${ }^{\circ}$ LEC) para revisar la grabación y resolver la controversia (o mejor, para que el tribunal pudiera resolver el recurso de reposición oral con arreglo a lo efectivamente acontecido en el trámite del art. 428.1 LEC). Si la disfunción apuntada se produce con ocasión de la práctica de la prueba personal o en la propia sentencia, siempre resultará más asequible contar con una transcripción de la grabación audiovisual de la audiencia previa y con el detalle del momento cronológico en que se fijó tal o cual hecho.

Ciertamente, lo más apropiado sería — desde un plano de lege feren$d a$, por supuesto- que la norma obligase al juez a efectuar algún pronunciamiento, siquiera fuera para establecer como definitivas las relaciones de hechos pacíficos y controvertidos - en el supuesto de no registrarse controversia entre los contendientes a este respecto y, desde luego, para resolver cualquier desencuentro manifiesto de las partes sobre el particular-. Siendo que se trataría de una resolución (en el primer caso, de una providencia, y en el segundo, de un auto), y por más que la misma sea oral, se vería indefectiblemente afectada por el principio de invariabilidad de los pronunciamientos judiciales (ex art. 214 LEC). De tal suerte que una variación posterior de un hecho reputado inicialmente pacífico o controvertido supondría conculcar este último precepto ${ }^{68}$.

68 A. Capilla Casco y J. Sánchez Lozano Velasco, «Patologías...», op. cit., p. 69, sos- 


\section{LA «EXHORTACIÓN» JUDICIAL DEL APARTADO 2. DEL ART. 428 LEC}

Debe reconocerse que esta concreta norma suscita $-\mathrm{O}$, al menos, debiera provocar - cierta inquietud, especialmente en los litigantes y de forma particular en sus defensas técnicas ${ }^{69}$. Y ello por varias razones que, como se verá, se resumen en dos. La primera de ellas es la enigmática expresión con que se inicia el texto: «a la vista del objeto de la controversia». No se sabe muy bien qué sea eso que, resultando tan visible, mueva al juez a exhortar a las partes para que lleguen a un acuerdo ${ }^{70}$. Dicho de otra forma, cabe preguntarse qué particular aspecto o qué singulares circunstancias debe presentar el objeto del pleito para que excite el celo judicial por la consecución de un pacto ${ }^{71}$. Además, no circunscribe el término «controversia» a los hechos, que es precisamente lo que se acaba de delimitar, sino que cabe extender su ámbito objetivo también a la disputa jurídica. La segunda de las razones para recelar del propósito último de la norma es la mayor implicación que exige del juez, al que le pide que «exhorte» a las partes a llegar a un acuerdo, lo que es empresa mayor que la simple comprobación de que subsiste la disputa, tarea que se le encomienda al órgano jurisdiccional en el trámite del art. 415 LEC, expresamente consagrado a la función conciliadora ${ }^{72}$.

tienen que lo que acontecería sería la vulneración del principio de congruencia de las resoluciones judiciales.

${ }^{69}$ Diría que también le resulta áspera a los jueces, lo que explicaría que en la práctica forense no se use esta facultad conciliadora, como señalan A. CAPILla CASCO y J. SÁnCHEZLOZANO Velasco, «Patologías...», op. cit., p. 67.

${ }^{70}$ Por lo general, la doctrina aplaude la dicción legal. Así, por todos, J. HoyA CoroMINA, «Art. 428...», op. cit., pp. 1904-1905. Para este último, lo actuado durante la audiencia previa -incluyendo de forma sorprendente, en mi opinión, la fase de depuración procesal- puede favorecer que las partes modifiquen la visión de sus intereses en el pleito que tenían al principio de la audiencia previa.

71 A. DE la Oliva Santos, «Introducción. Génesis de la audiencia previa en el juicio ordinario de la Ley de Enjuiciamiento Civil 1/2000», en A. DE LA Oliva SANTOS (coord.), El tratamiento de las cuestiones procesales y la audiencia previa al juicio en la Ley de Enjuiciamiento Civil, Madrid, Civitas, 2005, p. 32, afirma que la experiencia enseña que las partes son más propensas a alcanzar un acuerdo cuando han tomado conocimiento de las proporciones reales de la controversia. No comparto, sin embargo, tal aserto, porque, en mi opinión, lo que la experiencia muestra es que difícilmente los abogados optan por abandonar las hostilidades en el momento de la audiencia previa, a pesar, incluso, de que alberguen escasas esperanzas de tener éxito.

${ }^{72}$ Me parece interesante la mención de J. M. F. Paz Rubio, J. Achaerandio Guijarro, A. de Andrés Herrero, A. V. Illescas Rus, L. Puente Segura y C. Salgado Carrero, Ley de 
Decía antes que mi preocupación se resume en una sola cosa que abarca las anteriores. Sin tener muy claro qué ha cambiado - desde un punto de vista epistémico — en la mente del juez — en la parte final de la audiencia previa- y viendo algo que no sabemos qué sea en el contenido del trámite delimitador ${ }^{73}$, se le encomienda nada menos que la tarea de «exhortar» a las partes. Lo que quiero decir es que con tan sólo fijar los hechos pacíficos y controvertidos o tiende el juez a formarse una idea precipitada con una información de base pobre - a falta de la práctica de pruebao se abstendrá de impeler a los litigantes a que transijan ${ }^{74}$, valiéndose, en el mejor de los casos, de una fórmula ritual con escasa convicción ${ }^{75}$. Por todo ello, más que de gravar al tribunal con labores conciliadoras, bastaría con permitir a las partes que manifestasen su eventual voluntad de llegar a un acuerdo a la vista de las expectativas de éxito que resulten de la labor concretora ${ }^{76}$.

Por último, cabe interrogarse por si tal oportunidad de solución paccionada de la controversia cabe también en aquellos casos en que no habiendo disputa fáctica, toda la que reste sea de orden jurídico, en cuyo caso se pasa directamente al dictado de la sentencia. Aunque en la secuencia del precepto la eventual «exhortación» judicial para que las partes lle-

Enjuiciamiento Civil comentada..., op. cit., pp. 623-624, a las reticencias que ya los comentaristas de la ALEC albergaban con respecto a la «exhortación judicial». En cuanto a la diferencia entre la comprobación inicial de subsistencia del litigio y esta «exhortación final», vid. A. M. LorCa NAVARRETE, «La fase intermedia de audiencia de las partes del juicio ordinario que regula la nueva Ley de Enjuiciamiento Civil», Diario La Ley, Sección Doctrina, 2000, ref. D-28, t. 1, 2000, p. 24.

73 Para J. Banacloche PalaO, «Art. 428...», op. cit., p. 722, es posible que ahora el tribunal tenga una visión distinta a la que tenía al principio, aunque no especifica en qué consiste ese cambio de perspectiva.

${ }^{74}$ No se olvide que se trata efectivamente de una facultad, como subraya I. TAPIA FERNÁNDEZ, «Art. 428...», op. cit., p. 1801.

75 De aquí que J. DAmí́n Moreno, «La audiencia previa...», op. cit., p. 104, afirme que conviene que «los jueces observen un comportamiento exquisito en relación con las facultades que les otorga la ley en este sentido». Cualquier exceso de celo en la búsqueda de una solución paccionada al conflicto puede aparecer fundada, fácilmente, en cierto prejuicio sobre el fondo de la controversia. También se apresura J. BANAClOCHE PALAO, «Art. 428...», op. cit., p. 723, a subrayar la diferencia que debe existir entre «exhortar», «coaccionar» y «adelantar el contenido de la sentencia», lo que permite formarse una idea cabal de la sutil línea que separa a la primera de las dos segundas conductas.

${ }^{76}$ Por eso creo que el legislador se ha excedido en la redacción de la norma, habiéndole bastado con dejar una puerta abierta para que los litigantes pudieran transigir el pleito en este momento procesal, como, por otra parte, me parece entrever de las palabras de J. ALONSO-Cuevillas y SAYROL, «La audiencia previa...», op. cit., pp. 167-168, quien, no obstante, ensalza el precepto. Sobre este juicio acerca de las probabilidades de éxito a la vista del resultado del trámite que nos ocupa vid. E. Rodríguez Achútegui, «Art. 428...», op. cit., p. 2640. 
guen a un acuerdo antecede al tratamiento de los supuestos de inexistencia de disputa factual, no veo por qué debería impedirse un arreglo en estas circunstancias.

\section{EL TRATAMIENTO PROCESAL DE LA AUSENCIA DE CONTROVERSIA FÁCTICA}

Bien puede decirse que, en este punto, la norma no reviste especial dificultad. Como bien se recoge en el apartado 3. ${ }^{\circ}$ del art. 428 LEC, en caso de que la única controversia que subsista entre las partes sea la jurídica «el tribunal dictará sentencia dentro de veinte días a partir del siguiente al de la terminación de la audiencia». Por supuesto, llegado el momento de redactar el relato de hechos probados de la sentencia, el juez se encontrará vinculado en cuanto al factum, reputado todo él pacífico ${ }^{77}$.

Por otra parte, es frecuente que en la práctica se plantee la posibilidad de conceder un trámite de conclusiones previo al dictado de la sentencia. Se discute también si dicha oportunidad se satisface in actu, esto es, en la propia audiencia previa antes de darla por finalizada, o cabe evacuar el trámite por escrito, una vez concluido el acto procesal oral.

No son pocas las opiniones que abogan por la respuesta favorable. Se esgrimen, como principales argumentos, el tenor literal del art. 185.4 LEC, la aplicación analógica del art. 433.3 LEC y, en general, el favorecimiento de la contradicción ${ }^{78}$. No obstante, también se registran otras posturas contrarias a esta posibilidad, atendido que el tenor literal del art. 428.3 LEC no contempla tal posibilidad, a diferencia del art. 433.2, donde se reconoce expresamente. Empero, que se evacue tal informe de conclusiones no sería causa para decretar la nulidad de actuaciones ${ }^{79}$.

\section{LA INADECUADA LOCALIZACIÓN SISTEMÁTICA DEL ART. 428 LEC}

Tengo para mí que la vigente secuencia de los arts. 427 y 428 LEC debería ser seriamente reconsiderada. Bien es verdad que podría defen-

77 Cfr. STS, Sala 1. ${ }^{a}$, Sección 1. ${ }^{a}$, núm. 608/2016, de 7 de octubre (RJ 2016/4761).

78 Cfr. J. Arsuaga CoRTÁzAR, «Art. 428...», op. cit., p. 2051.

79 Sostiene tal postura E. Rodríguez Achútegui, «Art. 428...», op. cit., p. 2641. 
derse que entre los preceptos 426, 427 y 428 no existe un orden legal rígido e inquebrantable, quedando de esta forma a salvo la posibilidad de alternar de facto el orden de los arts. 427 y 428 LEC sin mayor proble$\mathrm{ma}^{80}$. En cualquier caso, no tiene especial sentido que la impugnación de documentos y dictámenes anteceda a la fijación de la controversia fáctica. Parece más sensato - y económico— que, en primer lugar, se delimiten los hechos disputados - y necesitados de prueba, documental inclui$\mathrm{da}-\mathrm{y}$ que, en segundo lugar, se produzca el pronunciamiento sobre los documentos. Y ello por cuanto que pudiera haber hechos que, por reputarse pacíficos, no requiriesen prueba de cualquier clase, tampoco documental ${ }^{81}$. Además, debe tenerse presente que, según estipulan los arts. 399 y 405 LEC, junto a los escritos rectores en los que se vierten las afirmaciones de hecho obran los documentos de los que quieren valerse las partes. Por consiguiente, puede que un hecho afirmado y documentado en la demanda devenga posteriormente pacífico, por admitirlo la contraparte, y no por ello el documento se desgajará de los autos. Pero es evidente que su utilidad deviene nula como consecuencia del carácter pacífico del hecho al que inicialmente servía como prueba.

\section{APUNTE FINAL: PROPUESTA DE LEGE FERENDA}

El acierto del precepto ha quedado visiblemente ensombrecido por las muchas lagunas que se advierten en su redacción. Completar el tenor literal con los elementos indispensables para dotar a la norma de mayor eficacia es lo que me lleva a postular la siguiente redacción literal, que se sugiere, al menos, como punto de partida para una discusión que a buen seguro resultará muy provechosa:

${ }^{80}$ E. Vallines García, «El acto de celebración de la audiencia previa al juicio», en A. DE LA Oliva SANTOS (coord.), El tratamiento de las cuestiones procesales y la audiencia previa al juicio en la Ley de Enjuiciamiento Civil, Madrid, Civitas, 2005, p. 393, afirma que «la mera sucesión numérica de esos tres artículos no entraña la existencia de orden legal dentro del trámite de fijación del objeto de la controversia, pues no hay ningún precepto que [...] así lo disponga, ni expresa ni tácitamente». No obstante la claridad de sus palabras, las matiza a renglón seguido y en la página siguiente al circunscribir esta posibilidad de alteración del orden o secuencia exclusivamente a los arts. 426 y 427 LEC.

${ }^{81}$ Así, J. Garberí Llobregat, Los procesos civiles, Barcelona, Bosch, p. 462. Por su parte, J. DE LA RÚA NAVARRO, «El "posicionamiento" ante documentos y dictámenes en la audiencia previa», en X. Abel Lluch y J. Picó i Junoy (dirs.) e Y. Ríos LóPez (coord.), Aspectos prácticos de la prueba civil, Barcelona, Bosch, 2006, p. 217 no se pronuncia al respecto, sosteniendo que el trámite debe estar entre la depuración de vicios procesales y la proposición de prueba. 
«428. Fijación de la controversia fáctica y jurídica y posible sentencia inmediata.

1. Los abogados de las partes manifestarán qué hechos consideran pacíficos y cuáles reputan controvertidos, interviniendo en primer lugar la parte actora, todo ello bajo la dirección del juzgador. En caso de que se suscite discusión en torno al carácter pacífico o controvertido de un hecho, los letrados justificarán su consideración remitiéndose a los escritos correspondientes y si se tratase de afirmaciones fácticas vertidas en el decurso de la audiencia previa, ésta se interrumpirá por el tiempo necesario para que el juez examine la grabación audiovisual. El juzgador resolverá la controversia por medio de resolución oral motivada, frente a la que únicamente cabrá recurso de reposición oral.

2. De igual forma, se deberán posicionar las partes, y resolver el juez, sobre las máximas de experiencia no especializadas que se hayan vertido en los escritos rectores o en la propia audiencia previa, siguiendo el trámite anteriormente recogido.

3. En este momento procesal deberán las partes manifestar si algún hecho de los alegados lo consideran notorio, debiéndose conceder oportunidad a la adversa para contradecir dicho carácter, teniendo que resolver el juez definitivamente sobre el particular.

4. Oídas las partes, el juez podrá decidir, mediante resolución oral motivada, eliminar cualquier afirmación de hecho que repute irrelevante o superflua.

5. Los abogados de las partes, siguiendo el modo de proceder fijado en el anterior apartado $1 .^{\circ}$, se posicionarán sobre las acciones y, eventualmente, excepciones materiales, aducidas de contrario, y sobre su fundamento normativo.

6. A partir de las manifestaciones concordes de las partes, o de las decisiones adoptadas por el juez, se levantará un acta exhaustiva en la que se recogerán los hechos pacíficos, los controvertidos, las máximas de experiencia, aceptadas o rechazadas, los hechos reputados notorios y el carácter conforme o disconforme de las acciones y, eventualmente, de las excepciones materiales ejercitadas e invocadas.

7. Cuando no exista controversia fáctica por tenerse todos los hechos por pacíficos o por notorios, el juzgador dictará sentencia dentro de los veinte días siguientes al de la terminación de la audiencia, sin darse término para evacuar conclusiones escritas u orales». 